\title{
Pengembangan E-Modul Menggunakan Software Flip PDF Profesional Materi Pecahan Kelas V Sekolah Dasar
}

\author{
Nurfadilla Yustina Putri*, Ni Luh Sakinah Nuraini, Erif Ahdhianto \\ Universitas Negeri Malang, Jl. Semarang No. 5 Malang, Jawa Timur, Indonesia \\ *Penulis korespondensi, Surel: yustinaputri001@gmail.com
}

Paper received: 25-8-2021; revised: 8-9-2021; accepted: 15-9-2021

\begin{abstract}
Field conditions show that learning fractions in class $\mathrm{V}$ requires innovative teaching materials. This study aims to test the validity and practicality of the developed E-Module. The ADDIE model is used in this development. Product validation got the results of 98.68 percent declared valid. Material validation got a percentage result of 83.33 percent declared valid. The practicality test from users (teachers) got a percentage result of 94.23 percent which was declared practical and the practicality test of students got a score of 88.59 percent which was declared practical. So the validation and practicality of the product are declared valid and practical.
\end{abstract}

Keywords: e-modul; fraction material; fifth grade

\begin{abstract}
Abstrak
Kondisi lapangan menunjukan pembelajaran pecahan di kelas $\mathrm{V}$ membutuhkan bahan ajar yang inovatif. Penelitian ini memiliki tujuan untuk menguji kevalidan dan kepraktisan E-Modul yang dikembangkan. Model ADDIE digunakan pada pengembangan ini. Validasi produk mendapat hasil 98,68 persen dinyatakan valid. Validasi materi mendapat hasil persentase sebesar 83,33 persen dinyatakan valid. Uji kepraktisan dari pengguna (guru) mendapat hasil persentase sebesar 94,23 persen dinyatakan praktis dan uji kepraktisan peserta didik mendapatkan nilai sebesar 88,59 persen dinyatakan praktis. Jadi validasi dan uji kepraktisan produk dinyatakan valid dan praktis.
\end{abstract}

Kata kunci: e-modul; materi pecahan; kelas V

\section{Pendahuluan}

Matematika merupakan salah satu muatan yang harus dipelajari dengan maksimal diperkuat dengan pendapat Mashuri (2019) yang menyatakan bahwa matematika memiliki peran penting untuk beberapa disiplin ilmu dan dapat mempengaruhi daya berpikir manusia, oleh karena itu matematika sangat penting diberikan untuk mengatasi masalah kesulitan peserta didik belajar matematika. Pada kegiatan sehari-hari sering dijumpai kegiatan yang melibatkan konsep matematika sehingga pembelajaran konsep matematika sangat perlu untuk dipahami, hal ini dilakukan untuk mempersiapkan peserta didik saat terjun di masyarakat. Menurut Mufarizuddin (2018) banyaknya permasalahan kesulitan belajar dalam matematika menjadikan suatu keharusan untuk segera dikenali dan kemudian diatasi.

Salah satu materi yang harus dikuasai dalam muatan matematika yaitu pecahan. Menurut Subanar, dkk. (2020) peserta didik sulit untuk memahami materi pecahan oleh karena itu materi pecahan di kurikulum sekolah dasar penting untuk dipelajari. Permasalahan kesulitan belajar pada materi pecahan harus diatasi karena akan diujikan sebagai syarat kelulusan dan sering digunakan dalam kehidupan sehari-hari.

Konsep materi pecahan pada kelas $\mathrm{V}$ diberikan sesuai dengan karakteristik peserta didik itu sendiri. Menurut Zuryanti, dkk. (2020) peserta didik umur 12-15 tahun dapat berpikir 
secara abstrak, logis, dan mampu mengambil keputusan. Di kelas $\mathrm{V}$ peserta didik harus mematangkan konsep-konsep yang ada di sekolah dasar sebagai bekal di kelas VI yang nantinya akan mempersiapkan untuk ke jenjang yang lebih tinggi yaitu Sekolah Menengah Pertama.

Salah satu bentuk dari bahan ajar yaitu modul. Menurut Riyana (2012) modul memiliki komponen petunjuk guru, LKS (lembar kegiatan siswa), soal latihan dan soal tes. Menurut Rahdiyanta (2016) Perkembangan zaman menjadikan modul dalam bentuk cetak dapat dikemas dalam bentuk digital atau biasa disebut E-Modul. Penggunaan E-Modul memiliki banyak keuntungan. Menurut Najuah (2020) E-Modul memiliki kelebihan berupa peserta didik lebih termotivasi untuk belajar, dapat digunakan secara mandiri, dan dapat diakses secara fleksibel. E-Modul dapat didesain berbentuk flipbook menggunakan software Flip PDF Professional, menurut Sriwahyuni, dkk. (2019) software Flip PDF Professional memiliki menu menambahkan tulisan, animasi gerak, video, link, dan audio.

Penelitian dan pengembangan pada E-Modul sebelumnya telah dilakukan oleh Ningtyas, dkk. (2020) untuk peserta didik kelas III materi bangun datar dengan rata-rata nilai 3,78 dengan dikategorikan baik dan praktis. Penelitian terdahulu oleh Putri, dkk. (2020) untuk peserta didik kelas IV materi perjuangan para pahlawan mendapatkan nilai dari validator 84,5\% dikategorikan layak. Terdapat beberapa hal yang membedakan pengembangan ini dengan pengembangan sebelumnya. Perbedaan tersebut terletak pada penggunaan software, materi, dan menunya. Peneliti menggunakan software flip PDF professional dengan materi pecahan pada kelas $\mathrm{V}$, terdapat games yang terhubung dengan quizizz, dan video penerapan konsep pecahan pada kegiatan yang sering peserta didik temui di sekitarnya dan selanjutnya dari video tersebut peserta didik diberikan kegiatan dari video tersebut.

Peneliti melakukan penelitian pengembangan untuk mengatasi kebutuhan nyata dan yang mendesak. Hasil observasi pada guru dan peserta didik kelas V SDN Sugihwaras 02 Kabupaten Bojonegoro bahwa sebagian besar peserta didik kesulitan mempelajari materi pecahan. Terlebih pada masa pandemi Covid-19 peserta didik melakukan kegiatan pembelajaran secara dalam jaringan. Dari hal tersebut peneliti tertarik untuk mengetahui seberapa valid dan praktis kegiatan pembelajaran dengan menggunakan modul berbentuk digital menurut ahli bahan ajar, ahli materi, dan pengguna.

\section{Metode}

Penelitian ini tergolong sebagai jenis Research and Development. Zakariah, dkk. (2020) menyatakan bahwa untuk menghasilkan produk tertentu dalam sebuah pengembangan dapat menggunakan metode R\&D. Produk yang dihasilkan dari pengembangan akan dilakukan pengujian kevalidan dan kepraktisan. Model ADDIE digunakan dalam penelitian dan pengembangan ini. Rayanto \& Sugianti (2020) menyatakan ADDIE memiliki langkah-langkah analisis, desain, pengembangan, implementasi, dan evaluasi. Pada tahap analisis dilakukan observasi dan wawancara mengenai lingkungan belajar peserta didik dan hal-hal yang menjadi kebutuhan selama kegiatan pembelajaran, selanjutnya dilakukan kegiatan menganalisis kurikulum (KI, KD, Indikator, dan tujuan). Pada tahap desain dilakukan kegiatan merancang konsep E-Modul mulai dari peralatannya dan spesifikasi. Tahap pengembangan dilakukan pembuatan produk sesuai desain dan pengumpulan saran dari ahli produk dan ahli materi serta dilakukan perbaikan terhadap produk. Pada implementasi produk yang telah direvisi 
diterapkan di kelas $\mathrm{V}$ dan diuji kepraktisan oleh pengguna. Tahap evaluasi dilakukan kegiatan mengevaluasi hasil akhir produk, komentar beserta saran didapat dari validator dan pengguna.

Jenis data kuantitatif dan kualitatif digunakan pada pengembangan ini. Wawancara, observasi, dan angket merupakan teknik pengumpulan data yang digunakan. Pengumpulan data menggunakan wawancara beserta observasi dilakukan untuk menggali data mengenai permasalahan dan kebutuhan dalam melakukan kegiatan pembelajaran, sedangkan angket pilihan bertujuan untuk menentukan kevalidan dan kepraktisan bahan ajar E-Modul. Data yang didapat akan dianalisis menggunakan teknik analisis data kualitatif dan kuantitatif. Data yang berasal dari wawancara, observasi, komentar beserta saran akan dilakukan analisis menggunakan teknik analisis kualitatif. Siyoto dan Sodik (2015) menyatakan bahwa teknik kegiatan mereduksi data dilakukan untuk mengkumpulkan dan memilih data yang penting. Penyajian data dilakukan pengelompokkan sesuai dengan pokok permasalahannya untuk dijabarkan. Pada tahap kesimpulan dilakukan penarikan kesimpulan terhadap data yang didapat. Ketiga proses tersebutlah yang digunakan untuk melakukan analisis data kualitatif. Penilaian pada setiap lembar validasi dan kepraktisan diberikan skala sebagai berikut, nilai 1 menunjukan bahwa penilaian yang diberikan menunjukkan hasil "Kurang Baik", nilai 2 menunjukan bahwa penilaian terhadap produk "Cukup Baik", nilai 3 menunjukkan bahwa produk yang dikembangkan tergolong "Baik", dan nilai 4 menunjukan bahwa produk yang dikembangkan "Sangat Baik".

Untuk mengetahui nilai validasi dan kepraktisan menggunakan rumus berikut.

$$
E=\frac{T S e}{T S h} \times 100 \%
$$

Hasil yang diperoleh kemudian disesuaikan dengan kriteria validasi. Pada tabel 1 kita dapat melihat nilai kriteria validitas.

Tabel 1. Kriteria Validasi E-Modul

\begin{tabular}{ccl}
\hline No & Kriteria Pencapaian Nilai (Kevalidan) & \multicolumn{1}{c}{ Kriteria Kevalidan } \\
\hline 1 & $81,00 \%-100,00 \%$ & Sangat valid dan dapat digunakan tanpa perbaikan \\
2 & $61,00 \%-80,00 \%$ & $\begin{array}{l}\text { Cukup valid dan dapat digunakan namun perlu } \\
\text { perbaikan kecil }\end{array}$ \\
& & Kurang valid dan perlu perbaikan besar \\
3 & $41,00 \%-60,00 \%$ & Tidak valid dan tidak bisa digunakan \\
4 & $21,00 \%-40,00 \%$ & Sangat tidak valid dan tidak bisa digunakan \\
5 & $00,00 \%-20,00 \%$ & \\
\hline
\end{tabular}

Sumber : Akbar (2015)

Sedangkan untuk mengetahui rumus kepraktisan dari pengguna menggunakan rumus berikut.

$V=\frac{T S e}{T S h} \times 100 \%$

Hasil yang diperoleh kemudian disesuaikan dengan kriteria kepraktisan E-Modul. Pada tabel 2 kita dapat melihat nilai kriteria kepraktisan. 
Tabel 2. Kriteria Kepraktisan E-Modul

\begin{tabular}{ccll}
\hline No. & Tingkat Pencapaian & Klasifikasi & Keterangan \\
\hline 1 & $81 \%-100 \%$ & Sangat baik & Sangat positif/ sangat praktis/ tidak perlu revisi \\
2 & $61 \%-80 \%$ & Baik & Positif/ praktis/ tidak perlu revisi \\
3 & $41 \%-60 \%$ & Cukup baik & Kurang positif/ kurang praktis/ perlu revisi \\
4 & $21 \%-40 \%$ & Kurang baik & Tidak positif/ tidak praktis/ perlu revisi \\
5 & $<20 \%$ & Sangat kurang baik & Sangat tidak positif/ sangat tidak praktis/ perlu revisi \\
\hline \multicolumn{2}{r}{ Sumber:Arikunto (2010) } & &
\end{tabular}

\section{Hasil dan Pembahasan}

\subsection{Hasil}

E-Modul dengan judul "Bergembira dengan Belajar Pecahan" merupakan hasil dari pengembangan ini. E-Modul tersebut membahas muatan matematika materi pecahan yang diperuntukan dalam melakukan pembelajaran di kelas V Sekolah Dasar. E-Modul memiliki bentuk fisik elektronik, dapat diakses secara online dan memiliki tebal 125 halaman. E-Modul memiliki tulisan dengan Font Times New Roman dan memiliki size 12. Terdapat gambar yang relevan dengan materi yaitu pecahan yang diilustrasikan dengan gambar buah-buahan. Selain itu E-Modul memiliki warna yang kontras. E-Modul dilengkapi dengan KI (Kompetensi Inti), KD (Kompetensi Dasar) yang selanjutnya dikembangkan dalam Indikator dan tujuan, petunjuk penggunaan, kata-kata motivasi, materi pecahan, contoh soal beserta penjelasannya, kegiatan peserta didik, games menggunakan quizizz, video pembelajaran yang terhubung dengan youtube, kolom harapan peserta didik.

Hasil evaluasi diperoleh dari ahli produk yaitu Bapak Eka Pramono Adi, S.IP., M.Si yang menjabat sebagai dosen Universitas Negeri Malang jurusan TEP. Hasil evaluasi materi dari Bapak Drs. Goenawan Roebyanto, M.Pd selaku dosen Universitas Negeri Malang Prodi PGSD. Evaluasi pada produk dilakukan pada tanggal 19 Mei 2021. Uji kevalidan dilakukan oleh Bapak Yusup,S.Pd. Bapak Yusup, S.Pd merupakan guru kelas V SDN Sugihwaras 2 Bojonegoro. Evaluasi pada produk dilakukan pada tanggal 24 Mei 2021. Dan 23 peserta didik kelas V SDN Sugihwaras pada tanggal 28 Mei 2021. Pada tabel 3 kita dapat melihat paparan data hasil uji validitas dan kepraktisan.

Tabel 3. Paparan Data Hasil Uji Validasi dan Kepraktisan

\begin{tabular}{llll}
\hline No & Validator/Kepraktisan & Persentase & \multicolumn{1}{c}{ Komentar dan saran } \\
\hline 1 & Validasi produk & $98,68 \%$ & Secara umum sudah baik. Dapat \\
& & dioptimalkan lagi dengan penambahan \\
& & fitur dan ragam media, misalnya berupa \\
& & animasi untuk peragaan konsep dan \\
& & operasi matematika sesuai konten, yang \\
& & diadopsi dari media umum atau internet, \\
& & dengan mencantumkan sumbernya. Layak \\
& & untuk dilanjutkan atau diimplementasikan \\
& & sesuai model pengembangan yang \\
& & digunakan. Potensial diintegrasikan dalam \\
& & LMS sekolah/lembaga. \\
\hline
\end{tabular}




\begin{tabular}{|c|c|c|c|}
\hline No & Validator/Kepraktisan & Persentase & Komentar dan saran \\
\hline 2 & Validasi materi & $83,33 \%$ & $\begin{array}{l}\text { Pada evaluasi dapat ditambahkan soal } \\
\text { HOTS dan kalimat pada materi sebaiknya } \\
\text { tidak terlalu mendoktrin. }\end{array}$ \\
\hline 3 & isan (guru) & 94,2 & Secara keseluruhan modul sudah baik. \\
\hline 4 & $\begin{array}{l}\text { Kepraktisan (peserta } \\
\text { didik) }\end{array}$ & $88,59 \%$ & $\begin{array}{l}\text { E-modul sangat membantu saya untuk } \\
\text { mengikuti pelajaran, } E \text {-modul juga sangat } \\
\text { menarik, jelas, dan sangat bermanfaat } \\
\text { untuk pelajaran saya. Dan lain sebagainya. }\end{array}$ \\
\hline
\end{tabular}

\subsection{Pembahasan}

E-Modul hasil pengembangan yang mengangkat muatan matematika dengan bahasan materi pecahan ditujukan untuk pembelajaran di kelas V Sekolah Dasar dilakukan melalui 5 tahap. Tahapan pengembangan dan penelitian yaitu analisis, desain, pengembangan, implementasi, dan evaluasi

\subsection{Analisis}

Langkah pertama pada pengembangan yang dilakukan yaitu analisis. Langkah pertama pada tahap analisis yaitu dilakukan studi lapangan, studi lapangan ditujukan untuk mengetahui kekhasan pada anak kelas $\mathrm{V}$ dan kebutuhan selama kegiatan pembelajaran yang dilakukan melalui observasi dan wawancara pada guru dan peserta didik kelas V SDN Sugihwaras 2 pada tanggal 18 Januari 2021. Hasil observasi menunjukkan bahwa kegiatan pembelajaran pecahan secara daring guru hanya menggunakan buku siswa dan video dari youtube, sehingga peserta didik merasa bosan dan kurang semangat untuk melakukan kegiatan pembelajaran secara disiplin. Dari hasil tersebut dibuat gagasan produk yang cocok untuk dikembangkan, selanjutnya yaitu menganalisis kurikulum mulai dari KI, KD, mengembangkan indikator, dan tujuan pembelajaran berdasarkan taksonomi bloom yang akan dijadikan pedoman materi pada produk. Hasil dari tahap ini yaitu berupa materi, contoh soal dan pembahasan, kegiatan peserta didik, video, ilustrasi gambar yang relevan, dan games.

\subsection{Desain}

Pada tahap desain dilakukan perancangan dan menyusun kerangka produk secara spesifik dan penggunaan alat yang digunakan untuk melakukan pengembangan produk. Berikut merupakan tahapan dalam mendesain produk. (1) Membuat konsep produk disesuaikan dengan materi (pecahan kelas V SD) dan karakteristik peserta didik. (2) Menyiapkan peralatan yang digunakan berupa Laptop, Software (Microsoft word, aplikasi Flip PDF Professional, kamera). (3) Membuat desain sampul depan, sampul belakang, serta video. (4) Menyusun isi $E$-Modul yang berupa petunjuk penggunaan materi, soal dan pembahasan, kegiatan peserta didik, video pembelajaran, gambar yang relevan, dan games. (5) Membuat produk yang masih dalam bentuk PDF menjadi E-Modul menggunakan aplikasi Flip PDF Professional.

\subsection{Pengembangan}

Pada tahapan pengembangan dilakukan kegiatan merealisasikan desain produk. Realisasi terhadap desain dimulai dengan pemenuhan alat berupa Microsoft word, aplikasi Flip 
PDF Professional dan kamera. Selanjutnya dilakukan pemenuhan bahan dengan menyusun materi pecahan beserta contoh soal dan pembahasannya, pembuatan video, gambar yang relevan, kumpulan latihan soal, dan kegiatan peserta didik. Setelah alat dan bahan terpenuhi selanjutnya yaitu penyusunan yang dilakukan dengan mempertimbangkan kekhasan pada peserta didik kelas V. Setelah produk yang dikembangkan jadi, selanjutnya dilakukan uji produk dengan melakukan validasi. Angket bentuk terbuka dan angket tertutup digunakan untuk melakukan pengujian validasi dilakukan oleh ahli bahan ajar dan ahli pada bidang materi.

Pengembangan E-Modul dari segi validasi produk dinilai dari tiga aspek penulisan, desain dan tampilan bahan ajar, dan kegunaan yang divalidasi Bapak Eka Pramono Adi, SIP, M.Si selaku ahli bahan ajar dengan hasil persentase sebesar 98,68 \% termasuk dalam kategori sangat valid. Sedangkan pada penelitian terdahulu oleh Haniati (2018) mendapatkan persentase $84 \%$ dinyatakan layak. Dari hal tersebut dapat dinyatakan bahwa produk yang dikembangkan pada pengembangan E-Modul Bergembira dengan Belajar Pecahan ini memiliki kevalidan lebih tinggi.

Pada materi terdapat tiga aspek yang digunakan untuk validasi yaitu kesesuaian materi, mendorong keingintahuan, dan penyajian yang dilakukan oleh Bapak Drs. Goenawan Roebyanto M.Pd. mendapatkan hasil persentase 83,33\% di kategori cukup valid. Sedangkan pada penelitian terdahulu yang dilakukan oleh Putri, dkk. (2020) dalam uji kevalidan materi mendapat nilai 80,5\%, dan Ningtyas, dkk. (2020) dalam uji validasi materi mendapat nilai $84,66 \%$ dinyatakan valid.

Penilaian juga didapatkan dari angket terbuka berupa komentar dan saran. Penilain dari angket terbuka dari Bapak Eka Pramono Adi, S.IP berkomentar dan memberi saran untuk menambahkan gambar yang relevan dengan materi. Komentar serta saran untuk validasi materi didapat dari Bapak Drs. Goenawan Roebyanto, M.Pd yang menyatakan bahwa pada $E$ Modul ditambahkan soal HOTS dan mengganti kalimat yang terkesan mendoktrin.

Berdasarkan komentar dan saran selanjutnya dilakukan revisi atau perbaikan. Dari hasil revisi produk ditambahkan gambar buah-buahan untuk dituliskan secara bentuk pecahannya, pemilihan gambar tersebut dikarenakan buah-buahan merupakan benda yang sering terlihat di sekitar peserta didik sehingga hal tersebut akan lebih mudah dipahami peserta didik. Selain itu revisi dilakukan dengan melakukan penggantian kalimat yang kaku atau terlalu mendoktrin dengan kalimat tanya dan ajakan yang mendorong peserta didik untuk berpikir lebih mendalam, revisi juga dilakukan dalam bentuk penambahan soal HOTS pada quizizz yang terdapat pada E-Modul.

\subsection{Implementasi}

Produk yang telah melalui tahap revisi selanjutnya dilakukan penerapan terhadap pengguna (guru serta peserta didik kelas V SDN Sugihwaras 2 Bojonegoro). Guru kelas berjumlah satu dan peserta didik berjumlah 23. Pelaksanaan kegiatan pembelajaran selama 3 kali pertemuan dengan menggunakan E-Modul yang dikembangkan. Setelah melakukan kegiatan pembelajaran tersebut guru dan peserta didik melakukan penilaian terhadap EModul melalui angket untuk menguji kepraktisan produk yang dikembangkan. Pada penelitian terdahulu yang dilakukan oleh Putri, dkk. (2020) uji kepraktisan didapatkan dari guru mendapat hasil $95,7 \%$ dan $90,5 \%$ dari peserta didik dan dinyatakan layak. Sedangkan 
pengembangan yang dilakukan kali ini penilaian kepraktisan dilakukan oleh Bapak Yusup, S.Pd sebagai guru kelas V SDN Sugihwaras dengan persentase kepraktisan 94,23\% dinyatakan sangat praktis. Uji kepraktisan juga dilakukan oleh 23 peserta didik kelas V SDN Sugihwaras 2 Bojonegoro dengan nilai persentase $88,59 \%$ dinyatakan sangat praktis.

\subsection{Evaluasi}

Setelah produk dilakukan uji kevalidan dan kepraktisan selanjutnya dilakukan analisis kekurangan pada produk yang dikembangkan. Peneliti terdahulu Sriwahyuni, dkk. (2019) mendapat hasil $75 \%$ dari ahli media sedangkan pada penelitian ini uji kevalidan didapatkan persentase sebesar $98,68 \%$ dari validator produk dan dinyatakan sangat valid. Uji kevalidan materi pada penelitian terdahulu oleh Denisa \& Luqman (2021) mendapat hasil 82\% sedangkan pada penelitian ini mendapatkan persentase kevalidan $83,33 \%$ dinyatakan sangat valid didapatkan dari validator materi. Guru kelas V memberikan persentase $94,23 \%$ dikategorikan sangat praktis dan 23 peserta didik kelas V memberikan persentase 88,59\% dikategorikan sangat praktis, sedangkan pada penelitian terdahulu oleh Oktaviara (2019) mendapatkan hasil kepraktisan dari peserta didik sebesar 94,4\%. Dengan begitu produk yang dikembangkan dapat dinyatakan valid dan praktis untuk diterapkan pada kegiatan pembelajaran matematika di kelas $\mathrm{V}$ materi pecahan.

\section{Simpulan}

Hasil penelitian dan pengembangan $E$-Modul muatan matematika materi pecahan untuk kelas V Sekolah Dasar mendapatkan persentase sebesar 98,68\% dinyatakan sangat valid dari validator ahli produk. Komentar dan saran yang didapat dari ahli produk yaitu berupa penambahan gambar yang relevan pada produk. Validasi materi pada E-Modul mendapatkan nilai validasi $83,33 \%$ dari ahli materi sehingga dinyatakan sangat valid dan mendapat komentar dan saran untuk menambah soal HOTS dan mengganti penggunaan kalimat yang mendoktrin menjadi menjadi kalimat yang dapat mengajak peserta didik untuk berpikir lebih mendasar. Uji kepraktisan mendapatkan 94,23\% dari guru kelas V dan 88,59\% dari peserta didik kelas V. Produk yang dilah dilakukan pengembangan dinyatakan praktis untuk diterapkan pada kegiatan pembelajaran pecahan di kelas V. Jadi berdasarkan pengujian validasi dan pengujian kepraktisan produk yang dikembangkan $E$-modul dinyatakan valid dan praktis untuk digunakan.

\section{Daftar Rujukan}

Akbar, S. (2015). Instrumen Perangkat Pembelajaran. Bandung: Remaja Rosdakarya.

Arikunto. (2010). Penilaian Program Pendidikan Edisi Ketiga. Jakarta: Bina Aksara.

Denisa, L., \& Hakim, L. (2021). Pengembangan E-Modul Kontekstual Akuntansi Perbankan Syariah Kelas XI Berbasis Flip Pdf Professional. Jurnal Pendidikan Akuntansi (JPAK), 9(1), 79-87.

Mufarizuddin, M. (2018). Analisis Kesulitan Pembelajaran Matematika Peserta didik Kelas V Sd Negeri 012 Bangkinang KOTA. Journal on Education, 1(1), 40-47.

Najuah, N., Lukitoyo, P.S., \& Wirianti, W. (2020). Modul Elektronik: Prosedur Penyusunan dan Softwarenya. Medan: Yayasan Kita Menulis.

Ningtyas, A. S., Triwahyuningtyas, D., \& Rahayu, S. (2020). Pengembangan E-Modul Bangun Datar Sederhana Berbasis Problem Based Learning (PBL) Menggunakan Software Kvsoft Flipbook Maker Untuk Peserta didik Kelas III. In Prosiding Seminar Nasional PGSD UNIKAMA (Vol. 4, No. 1, pp. 10-19). https://conference.unikama.ac.id/artikel/index.php/pgsd/article/view/446/356 
Oktaviara, R. A., \& Pahlevi, T. (2019). Pengembangan E-modul Berbantuan Kvisoft Flipbook Maker Berbasis Pendekatan Saintifik pada Materi Menerapkan Pengoperasian Aplikasi Pengolah Kata Kelas X OTKP 3 SMKN 2 Blitar. Jurnal Pendidikan Administrasi Perkantoran (JPAP), 7(3).

Putri, I. P., Yuniasih, N., \& Sakdiyah, S. H. (2020). Pengembangan E-Modul Berbasis Flip PDF ProfessionalPerjuangan Para Pahlawan di Kelas IV Sekolah Dasar. In Prosiding Seminar Nasional PGSD UNIKAMA (Vol. 4, No. 1, pp. 523-530).

Rahdiyanta, D. (2016). Teknik penyusunan modul. http://staff. uny. ac. id/sites/default/files/penelitian/drdwi-rahdiyanta-mpd/20-teknik-penyusunan-modul. pdf. diakses, 10.

Rayanto, Y.H., \& Sugianto. (2020). Penelitian Pengembangan Model Addie Dan R2d2: Teori \& Praktek. Pasuruan: Lembaga Academic \& Research Institute.

Riyana, C. 2012. Media Pembelajaran. Jakarta: KEMENAG RI.

Siyoto, S \& Sodik, M.A. (2015). Dasar Metodologi Penelitian. Yogyakarta: Literasi Media Publishing.

Sriwahyuni, I., Risdianto, E., \& Johan, H. (2019). Pengembangan bahan ajar elektronik menggunakan flip PDF professional pada materi alat-alat optik di SMA. Jurnal Kumparan Fisika, 2(3), 145-152.

Subanar, Solikhatun, \& Susyanto, N. (2020). Senarai Penelitian Seminar Nasional Matematika Ke-11 Universitas Gadjah Mada "Peran Matematika Dalam Pemodelan Risiko Keuangan Yogyakarta, 22 September 2019". Yogyakarta: Deepublish.

Zakariah, M.A, Afriani, V., Zakariah, M. (2020). Metodologi Penelitian Kualitatif, Kuantitatif, Action Research, Research And Development ( $N$ D). Kolaka: Yayasan Pondok Pesantren Al Mawaddah Warrahmah Kolaka.

Zuryanti, Hamidah, Kenedi, A.K., Helsa, Y. (2020). Pembelajaran STEM di sekolah Dasar. Yogyakarta: Deepublish. 